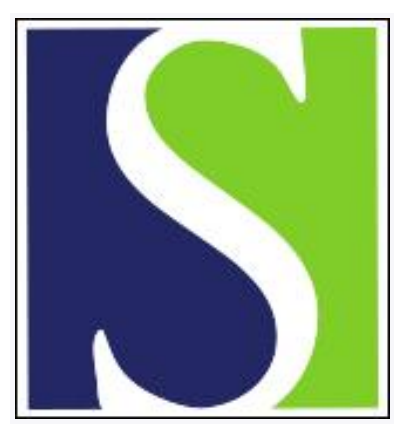

Scand J Work Environ Health 1981;7(2):84-94

https://doi.org/10.5271/sjweh.2561

Issue date: Jun 1981

\title{
Exposure to acetone. Uptake and elimination in man.
}

by Wigaeus E, Holm S, Åstrand I

Key terms: acetone; alveolar air; arterial blood; elimination; exercise; exposure; human; man; rest; uptake; urine; venous blood

This article in PubMed: www.ncbi.nlm.nih.gov/pubmed/6797062

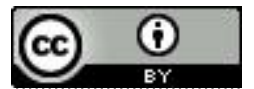




\title{
Exposure to acetone
}

\section{Uptake and elimination in man}

\author{
by Ewa Wigaeus, BSc, Stina Holm, BSc, Irma Åstrand, MD '
}

\begin{abstract}
WIGAEUS E, HOLM S, ÅTRAND I. Exposure to acetone: Uptake and elimination in man. Scand $j$ work environ health 7 (1981) 84-94. Eight male subjects were exposed to acetone vapor on two occaslions for $2 \mathrm{~h}$ in the laboratory. On the first occasion they were exposed to about $1,300 \mathrm{mg} / \mathrm{m}^{3}$ during rest and on the second occasion ito about $700 \mathrm{mg} / \mathrm{m}^{3}$ during rest $(30 \mathrm{~min})$ and exercise at different work loads on a bicycle ergometer $(90 \mathrm{~min})$. The total uptake of acetone was $0.6-1.2 \mathrm{~g}$, and the relative uptake was about $45 \%$. The concentration of acetone in alveolar air was $30-40 \%$ of that in the inspiratory air, and it was not affected by exposure time or work load. The concentration of acetone in blood increased continuously with increased uptake during exposure, and there was no tendency towardis equilibrium. The half-time of acetone in alveolar air as about $4 \mathrm{~h}$, and in venous and arterial blood it was about 6 and $4 \mathrm{~h}$, respectively. The highest concentrations of acetone in urine were measured $3-3.5 \mathrm{~h}$ after expasure. The ellimination of acertone via the Iungs corresponded to about $20 \%$ of the total uptake. Only about $1 \%$ of the upltake was excreted via urine.
\end{abstract}

Key terms: alveolar air, arterial blood, exercise, human, rest, urine, venous blood.

Acetone is a common solvent and extraction agent. It is used, eg, in the manufacture of pharmaceuticals and other chemicals and as a cleaning agent, eg, in styrene work in the fiberglass boat industry.

Acetone is highly volatile, and its vapor has an irritating effect on the mucous membranes of the eyes, nose, and throat. The Swedish threshold limit value has been set at $1,200 \mathrm{mg} / \mathrm{m}^{3}(500 \mathrm{ppm})$ and is primarily based on the irritant action of the vapor. However, adverse effects from acetone have been found at lower concentrations. Thus, a prolonged reaction time was noted in workers exposed to about $480 \mathrm{mg} / \mathrm{m}^{3}(200 \mathrm{ppm})(8)$, and physiological effects on the autonomic nervous system were found when exposure ex-

1 Department of Occupational Health, National Board of Occupational Safety and Health, Solna, Sweden.

Reprint requests to: Ms Ewa Wigaeus, Department of Occupational Healith, National Board of Occupational Safety and Health, S-171 84 Solna, Sweden. ceeded $600 \mathrm{mg} / \mathrm{m}^{3}(250 \mathrm{ppm})$ (13). The uptake and elimination of acetone have previously been studied, and a relative uptake varying between 14 and $86 \%$ has been reported $(6,10)$.

One reason for making acetone the subject of study at our laboratory was that its chemical properties differ from the properties of the solvents we have previously studied. The solubility of acetone in water is infinite, and its blood/air partition coefficient is extremely high when compared to that of many other solvents $(9,12)$. Small amounts of acetone are also endogenically formed in the body as a product of normal fat metabolism.

\section{Experimental design}

The subjects were eight healthy men, 2228 a of age. In a careful health examination prior to exposure, they all proved to be healthy, and none had ever had a disease judged to be capable of influencing the results of the present study. 
The anthropometric measurements of the subjects and the results of the pulmonary function tests and results from submaximal and maximal exercise tests on a bicycle ergometer were all of normal values (1).

Exposure was carried out after the initial examinations. The subjects were exposed to acetone via inspiratory air with the aid of a valve and mouthpiece. Exposure lasted $2 \mathrm{~h}$ on two different occasions at intervals of at least two months. On the first occasion, the subjects were exposed to an acetone concentration of approximately $1,300 \mathrm{mg} / \mathrm{m}^{3}$ during rest for $120 \min (30+30+30+30 \mathrm{~min})$ (series 1). On the second occasion, they were exposed to approximately $700 \mathrm{mg} / \mathrm{m}^{3}$ at rest for $30 \mathrm{~min}$ and during exercise on a bicycle ergometer for $90 \mathrm{~min}$. The work load of four subjects was $50 \mathrm{~W}(30+30+$ $30 \mathrm{~min}$ ) (series $2 \mathrm{a}$ ), and that of the other four subjects was increased stepwise from 50 to 100 to $150 \mathrm{~W}(30+30+30 \mathrm{~min})$ (series 2 b).

A 4-h monitored period of elimination in the laboratory followed the exposure. Physical activity consisted of a standardized mixture of rest and treadmill walking (5 min every half hour). The treadmill velocity and inclination were selected so that the load on the respiratory and circulatory organs was equivalent to about $\mathbf{5 0}$ $\mathrm{W}$ on a bicycle ergometer.

Table 1 lists the variables studied and the schedule used for the sampling and registration during and after exposure until the following morning.

\section{Methods}

To form the acetone/air mixture, compressed air was allowed to pass through two wash-bottles containing acetone. The acetone vapor obtained was then diluted with air in a mixing box until the desired concentration was attained. The acetone concentration in inspiratory air (table 2) was continuously monitored with a hydrocarbon analyzer (Scott model 116).

A device was built to prevent acetone from being lost in the gas phase because of condensation in the system during the collection of expiratory air. It consisted of a metal tube, thermostatically maintained at $37^{\circ} \mathrm{C}$ with the aid of a heating coil wound around it, connected to the expiratory side of the respiratory valve.

Expiratory air was collected continuously. It was passed alternately into an ordinary Douglas bag and a smaller bag made of polyester-laminated aluminum foil

Table 1. Variables studied at the laboratory and a schedule for the sampling and registration during and after exposure.

\begin{tabular}{|c|c|c|}
\hline \multirow{2}{*}{ Variable } & \multicolumn{2}{|r|}{ Schedule } \\
\hline & During exposure & After exposure \\
\hline \multicolumn{3}{|l|}{ Acetone concentration } \\
\hline Inspiratory air & Continuous & - \\
\hline Expiratory air & $2-3$ times/Douglas bag & $\begin{array}{l}0-16 \min : 3 \text { times/Douglas bag } \\
\text { (a total of } 6-7 \text { sampling occasions) }\end{array}$ \\
\hline $\left.\begin{array}{l}\text { Alveolar air } \\
\text { Arterial blood } \\
\text { Venous blood }\end{array}\right\}$ & $\begin{array}{l}\text { Every 5th } \min \text { and more } \\
\text { frequently at the start } \\
\text { of exposure and a new } \\
\text { work load }\end{array}$ & $\begin{array}{l}0-16 \mathrm{~min}: 1,3,5,10 \text { and } 15 \mathrm{~min} ; 16 \mathrm{~min} \\
-2 \mathrm{~h} \text { : every } 15 \mathrm{~min} ; 2-4 \mathrm{~h} \text { : every } 30 \mathrm{~min} \\
4-20 \mathrm{~h} \text { : alveolar air samples after } 10 \mathrm{~h} \\
\text { and } 20 \mathrm{~h} \text { and capillary blood samples } \\
\text { after } 20 \mathrm{~h}\end{array}$ \\
\hline Urine & - & $\begin{array}{l}\text { All urine samples were collected until the } \\
\text { following morning }\end{array}$ \\
\hline $\begin{array}{l}\text { Heart rate } \\
\text { Electrocardiagram }\end{array}$ & $\begin{array}{l}\text { Every other minute } \\
\text { Every } 5 \mathrm{~min}\end{array}$ & - \\
\hline Pulmonary ventilation & $\begin{array}{l}\text { Continuously with the } \\
\text { Douglas-bag technique }\end{array}$ & $\begin{array}{l}\text { 0-16 min: continuously with the Douglas- } \\
\text { bag technique; } 16 \text { min-4 } \mathrm{h} \text { : for } 5 \text {-min } \\
\text { periods each hour at rest and during } \\
\text { treadmill walking, with a Wright respiro- } \\
\text { meter }\end{array}$ \\
\hline Respiratory rate & 3 times/Douglas bag & - \\
\hline Oxygen uptake & $\begin{array}{l}\text { At the end of each } \\
30-\mathrm{min} \text { period }\end{array}$ & - \\
\hline
\end{tabular}


placed in a metal box thermostatically maintained at $37^{\circ} \mathrm{C}$. The aluminum bag was evacuated with a pump via a gas meter.

The air samples were taken with a gastight syringe via a membrane in conjunction with evacuation, and the acetone concentration was assayed by gas chromatography.

The air volume in the Douglas bags was measured with a spirometer, and the air volume in the foil bags (about 6 l) was

Table 2. Acetone concentration (time-weighted average for the entire period of exposure) in inspiratory air and the variation during each experimental session in the different experimental series. The variation in each experimental session was calculated as the difference between the highest and lowest concentration. The mean values \pm the standard errors are given.

\begin{tabular}{ccc}
\hline Series & $\begin{array}{c}\text { Concentration in } \\
\text { inspiratory air } \\
\left(\mathrm{mg} / \mathrm{m}^{3}\right)\end{array}$ & $\begin{array}{c}\text { Intraexperiment } \\
\text { variation } \\
\left(\mathrm{mg} / \mathrm{m}^{3}\right)\end{array}$ \\
\hline 1 & $1,309 \pm 43.4$ & $19.6 \pm 7.3$ \\
$2 \mathrm{a}$ & $712 \pm 15.8$ & $26.7 \pm 10.9$ \\
$2 \mathrm{~b}$ & $737 \pm 10.2$ & $20.1 \pm 8.4$ \\
\hline
\end{tabular}

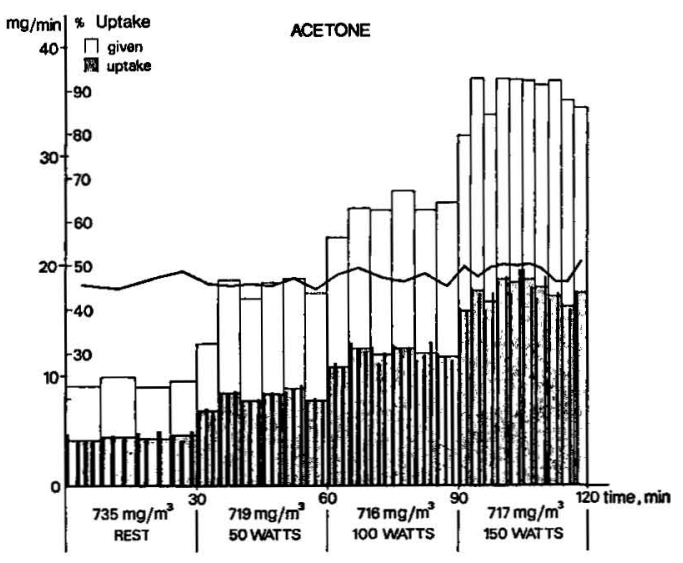

Fig 1. The amount of acetone administered and taken up and the percentage (horizontal boldface line) of the uptake during each Douglasbag period for a representative subject in series $2 b$. The acetone concentration in inspiratory air averaged $722 \mathrm{mg} / \mathrm{m}^{3}$. The exposure was performed with the subject at rest $(30 \mathrm{~min})$ and during exercise with a stepwise increased work load, ie, 50, 100 and $150 \mathrm{~W}(30+30+30 \mathrm{~min})$ $(1.2 \mathrm{~g}$ of the $2.6 \mathrm{~g}$ of the acetone administered was taken up in the body). added. Pulmonary ventilation was calculated for each Douglas-bag period.

The acetone concentration in the expired air wras calculated as the time-weighted average for the concentration in the two to three foil bags filled during the same period. The amount of acetone taken up was calculated as the difference between the amount inspired and expired during the period (fig 1).

The oxygen and carbon dioxide concentration in expiratory air was analyzed (Beckman OM-11 and Beckman LB-2, respectively) in the last Douglas bag during each 30 -min period, and oxygen uptake was calculated.

The acetone concentration in alveolar air was analyzed with a gas chromatograph after sampling with a gas-tight syringe from an outlet in the respiratory valve. Inspiration and expiration were registered with a thermistor, located in the inspiratory valve and connected to an oscilloscope, and samples were taken after a normal exhalation. Before and after exposure, the samples were either collected in glass tubes (about $35 \mathrm{ml}$ ) or, when a Wright respirometer was employed, in the same way as during exposure.

Blood and urine samples (approximately 0.5 and $1.0 \mathrm{ml}$, respectively) were analyzed by gas chromatography using a headspace technique. The samples were equilibrated with air at $37^{\circ} \mathrm{C}$ for $20 \mathrm{~min}$ in gastight bottles with accurately determined volumes (approximately $15 \mathrm{ml}$ ) and fitted with screw caps containing aluminum foiled rubber septums. Headsplace air $(0.5 \mathrm{ml})$ was withdrawn with a gas-tight syringe and analyzed by gas chromatography. The concentration of acetone in blood and urine was calculated from the headspace concentration, and the partition coefficient determined between blood or urine and air for each individual on the two exposure occasions.

The partition coefficients and the endogenic acetone concentrations were determined from identical incubations of control blood or urine before each exposure. To each control sample, a known amount of acetone diluted with a $0.9 \%$ saline solution had been added. The acetone concentration in the air phase was plotted as a function of the concentration in the liquid phase. The ratio was linear for the 
concentration range in question, $1-60 \mathrm{mg}$ / $\mathrm{kg}(0.017-1.0 \mathrm{mmol} / \mathrm{kg})$. The partition coefficient and endogenic concentration were calculated from the equation for the straight line (fig 2).

The gas chromatographic analyses were carried out with Perkin Elmer F11, F30 and F33 models, all equipped with a flame ionization detector. For the analysis of expired air, a 1-m long stainless steel column was used, packed with $8 \%$ Carbowax 1540 on Chromosorb W 80-100 mesh. The column temperature was $50^{\circ} \mathrm{C}$, and the flow rate of the carrier gas nitrogen was $25 \mathrm{ml} / \mathrm{min}$. Alveolar air was analyzed at $90^{\circ} \mathrm{C}$ with a $2-\mathrm{m}$ long glass column packed with $6 \%$ polyphenylether on Tenax. The flow rate of the carrier gas nitrogen was $30 \mathrm{ml} / \mathrm{min}$. A $0.3-\mathrm{m}$ long stainless steel column, packed with Porapac $Q$, with a nitrogen carrier gas flow of $25 \mathrm{ml} / \mathrm{min}$ and a column temperature of $130^{\circ} \mathrm{C}$, was employed for the blood and urine assays.

The amount of acetone expired after the exposure was calculated for the first 16 min in the same way as during the exposure, ie, with the Douglas-bag technique. Thereafter, and until the following morning, the amount of expired acetone was calculated as the product of alveolar ventilation and alveolar concentration. Alveolar ventilation $\left(\dot{V}_{A}\right)$ during the first $4 \mathrm{~h}$ after exposure was calculated from the formula $\dot{\mathrm{V}}_{\mathrm{A}}=\dot{\mathrm{V}}_{\mathrm{E}}$ - deadspace $\times$ respiratory rate $\left(\dot{\mathrm{V}}_{\mathrm{E}}=\right.$ total ventilation measured with a Wright respirometer; deadspace was set at $150 \mathrm{~m}^{3}$; respiratory rate was counted during the same period). For the next $16 \mathrm{~h}$ alveolar ventilation was set at $10 \mathrm{l} / \mathrm{min}$ for the first $6 \mathrm{~h}$ and $5 \mathrm{l} / \mathrm{min}$ for the last $10 \mathrm{~h}$. The expired quantity in milligrams per minute was plotted versus time in a diagram. A fitted curve was drawn, and the area under the curve was measured with a planimeter.

\section{Results}

During the exposure, the uptake of acetone was about $45 \%(39-52 \%)$ of the amount administered. Table 3 and fig 3 list the total and relative uptake of acetone in the three series. At an increased work load and with an attendant increase in pulmonary ventilation (table 4), the amount of acetone administered naturally increased. The amount taken up increased as the quantity supplied was increased (fig 3), and no significant change in relative uptake was noted (table 3 \& fig 1). The total uptake averaged $0.6 \mathrm{~g}$ in series 1 , $0.7 \mathrm{~g}$ in series $2 \mathrm{a}$, and $1.2 \mathrm{~g}$ in series $2 \mathrm{~b}$ (table 3).

Table 3 and fig 4 show the acetone concentration in alveolar air and arterial and venous blood. The endogenic acetone concentration in alveolar air averaged $1.7 \pm$ $0.5 \mathrm{mg} / \mathrm{m}^{3}$ (= mean value and standard deviation; henceforth all values are given this way unless otherwise specified). The alveolar acetone concentration increased during the first minute of exposure from the endogenic level to $30-40 \%$ of the concentration in inspiratory air. It then remained relatively constant throughout the entire exposure, both during rest and exercise (fig 4 \& table 3 ). The ratio between relative uptake and the alveolar concentration as a percentage of the concentration in the inspiratory air correlated well with the ratio found for solvents previously studied (fig 5).

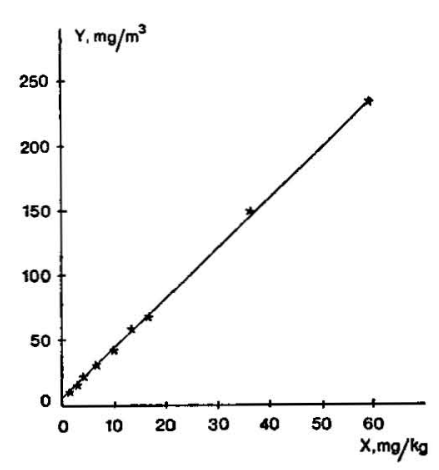

Fig 2. A representative standard curve for the determination of one subject's partitition coefficient between blood $(\mathrm{mg} / \mathrm{kg})$ and air $(\mathrm{mg} / \mathrm{l})$ and the endogenic concentration in blood. Regression line: $y=m x+b \quad(=3.86 x+5.39 a) ; y=$ acetone concentration in headspace $\left(\mathrm{mg} / \mathrm{m}^{3}\right)$; $x=(A A-A H) / A B[\mathrm{mg} / \mathrm{kg}]$ where $A A=$ amount of acetone administered $(\mathrm{mg}), \mathrm{AH}=$ total quantity in headspace $(\mathrm{mg}), A B=$ amount of blood (kg). Partition coefficient: $K=10^{3} / \mathrm{m} \quad(=259 \mathrm{a})$. Endogenic concentration: $E=\mathrm{b} / \mathrm{m}$ [mg/kg] (= $1.4 \mathrm{mg} / \mathrm{kg}$ a). Deviation from the line $(\mathrm{SD})=$ $\pm 1.1 ; r=1.00$.

a Result from the line illustrated in the figure. 
Table 3. Experimental data during exposure to acetone at rest and during exercise: The amount of acetone taken up (U), the relative uptake of acetone $(R)$ and the concentration of acetone in alveolar air, arterial and venous blood at the end of each 30-min period. Series 1: exposure at rest $(30+30+30+30 \mathrm{~min})$ to an average of $1,309 \mathrm{mg} / \mathrm{m}^{3}$; series $2 \mathrm{a}$ : exposure at rest ( 30 min) and at $50 \mathrm{~W}$ on a bicycle ergometer $(30+30+30 \mathrm{~min})$ to an average of $712 \mathrm{mg} / \mathrm{m}^{3}$; series $2 \mathrm{~b}$ : exposure at rest $(30 \mathrm{~min})$ and at 50,100 and $150 \mathrm{~W}$ on a bicycle ergometer $(30+30+30 \mathrm{~min})$ to an average of $737 \mathrm{mg} / \mathrm{m}^{3}$. The mean values \pm the standard errors of the means are given (series 1: $\mathrm{N}=8$; series $2 \mathrm{a}$ and $2 \mathrm{~b}: \mathrm{N}=4)$. ( $1 \mathrm{mg}=0.017 \mathrm{mmol})$

\begin{tabular}{|c|c|c|c|c|c|c|}
\hline \multirow[b]{2}{*}{ Series } & \multirow{2}{*}{$\begin{array}{l}\text { Period } \\
\text { of } \\
\text { time } \\
\text { (min) }\end{array}$} & \multirow[b]{2}{*}{$\underset{(\mathrm{mg})}{U}$} & \multirow[b]{2}{*}{$\underset{(\%)}{R}$} & \multicolumn{3}{|c|}{ Acetone concentration } \\
\hline & & & & $\begin{array}{l}\text { Alveolar } \\
\text { air } \\
\left(\mathrm{mg} / \mathrm{m}^{3}\right)\end{array}$ & $\begin{array}{l}\text { Arterial } \\
\text { blood } \\
(\mathrm{mg} / \mathrm{kg})\end{array}$ & $\begin{array}{l}\text { Venous } \\
\text { blood } \\
\text { (mg/kg) }\end{array}$ \\
\hline 1 & $\begin{array}{r}0-30 \\
30-60 \\
60-90 \\
90-120 \\
0-120\end{array}$ & $\begin{array}{l}146 \pm 9 \\
148 \pm 9 \\
142 \pm \\
144 \pm \\
580 \pm 32\end{array}$ & $\begin{array}{l}43 \pm 1 \\
43 \pm 1 \\
44 \pm 2 \\
44 \pm 2 \\
44 \pm 1\end{array}$ & $\begin{array}{l}497 \pm 48 \\
515 \pm 27 \\
500 \pm 25 \\
503 \pm 23\end{array}$ & $\begin{array}{r}7.1 \pm 0.4 \\
9.6 \pm 0.3 \\
12.5 \pm 0.4 \\
14.8 \pm 0.4\end{array}$ & $\begin{array}{l}4.3 \pm 0.5 \\
6.6 \pm 0.5 \\
8.4 \pm 0.4 \\
9.9 \pm 0.6\end{array}$ \\
\hline $2 a$ & $\begin{array}{r}0-30 \\
30-60 \\
60-90 \\
90-120 \\
0-120\end{array}$ & $\begin{array}{r}91 \pm 12 \\
208 \pm 10 \\
216 \pm 14 \\
206 \pm 16 \\
721 \pm 50\end{array}$ & $\begin{array}{l}43 \pm 2 \\
46 \pm 2 \\
45 \pm 3 \\
43 \pm 2 \\
44 \pm 2\end{array}$ & $\begin{array}{l}258 \pm 28 \\
244 \pm 19 \\
231 \pm 20 \\
256 \pm 16\end{array}$ & $\begin{array}{r}4.4 \pm 0.4 \\
8.8 \pm 0.4 \\
12.7 \pm 1.1 \\
16.9 \pm 1.8\end{array}$ & $\begin{array}{r}3.6 \pm 0.3 \\
7.5 \pm 0.7 \\
11.8 \pm 1.6 \\
15.3 \pm 1.6\end{array}$ \\
\hline $2 b$ & $\begin{array}{r}30-60 \\
60-90 \\
90-120 \\
0-120 \\
0-30\end{array}$ & $\begin{array}{r}228 \pm 5 \\
339 \pm 9 \\
471 \pm 19 \\
1,153 \pm 37 \\
115 \pm 6\end{array}$ & $\begin{array}{l}46 \pm 0 \\
46 \pm 1 \\
46 \pm 2 \\
46 \pm 1 \\
44 \pm 1\end{array}$ & $\begin{array}{l}325 \pm 33 \\
249 \pm 14 \\
234 \pm 14 \\
262 \pm 22\end{array}$ & $\begin{array}{r}4.8 \pm 0.3 \\
9.0 \pm 0.3 \\
15.9 \pm 1.0 \\
25.4 \pm 1.2\end{array}$ & $\begin{array}{r}3.2 \pm 0.3 \\
6.2 \pm 0.5 \\
12.2 \pm 0.7 \\
21.9 \pm 0.4\end{array}$ \\
\hline
\end{tabular}

Table 4. Physiological variables during exposure to acetone at rest and during exercise. Series 1 : exposure at rest $(30+30+30+30 \mathrm{~min})$ to an average of $1,309 \mathrm{mg} / \mathrm{m}^{3}$; series $2 \mathrm{a}$ : exposure at rest $(30 \mathrm{~min})$ and at $50 \mathrm{~W}$ on a bicycle ergometer $(30+30+30 \mathrm{~min})$ to an average of $712 \mathrm{mg} / \mathrm{m}^{3}$; series $2 \mathrm{~b}$ : exposure at rest $(30 \mathrm{~min})$ and at 50,100 and $150 \mathrm{~W}$ on a bicycle ergometer $(30+30+$ $30 \mathrm{~min}$ ) to an average of $737 \mathrm{mg} / \mathrm{m}^{3}$. The mean values \pm the standard errors of the means are given (series 1: $N=8$; series $2 \mathrm{a}$ and $2 \mathrm{~b}: \mathrm{N}=4)$. $(1 \mathrm{mg}=0.017 \mathrm{mmol}$ )

\begin{tabular}{cccccc}
\hline Series & $\begin{array}{c}\text { Period } \\
\text { of time } \\
(\mathrm{min})\end{array}$ & $\begin{array}{c}\text { Work } \\
\text { load } \\
(\mathrm{W})\end{array}$ & $\begin{array}{c}\text { Heart rate } \\
\text { (beats/min) }\end{array}$ & $\begin{array}{c}\text { VO }_{2} \\
(\mathrm{I} / \mathrm{min})\end{array}$ & $\begin{array}{c}\text { VE BTPS } \\
(\mathrm{I} / \mathrm{min})\end{array}$ \\
\hline \multirow{2}{*}{1} & $0-30$ & 0 & $69 \pm 4$ & $0.31 \pm 0.02$ & $9.1 \pm 0.5$ \\
& $30-60$ & 0 & $68 \pm 4$ & $0.31 \pm 0.02$ & $9.2 \pm 0.5$ \\
& $60-90$ & 0 & $65 \pm 4$ & $0.32 \pm 0.02$ & $8.9 \pm 0.5$ \\
& $90-120$ & 0 & $64 \pm 4$ & $0.31 \pm 0.01$ & $9.1 \pm 0.4$ \\
$2 \mathrm{a}$ & $0-30$ & 0 & $79 \pm 7$ & $0.34 \pm 0.03$ & $10.3 \pm 1.2$ \\
& $30-60$ & 50 & $102 \pm 10$ & $0.92 \pm 0.01$ & $22.5 \pm 0.8$ \\
& $60-90$ & 50 & $105 \pm 11$ & $0.98 \pm 0.03$ & $24.5 \pm 0.7$ \\
& $90-120$ & 50 & $107 \pm 10$ & $0.96 \pm 0.04$ & $24.4 \pm 0.8$ \\
$2 \mathrm{~b}$ & $0-30$ & 0 & $64 \pm 2$ & $0.39 \pm 0.04$ & $12.2 \pm 0.5$ \\
& $30-60$ & 50 & $82 \pm 1$ & $0.93 \pm 0.01$ & $23.7 \pm 0.7$ \\
& $60-90$ & 100 & $110 \pm 5$ & $1.45 \pm 0.01$ & $35.3 \pm 0.7$ \\
& $90-120$ & 150 & $142 \pm 6$ & $2.10 \pm 0.02$ & $50.1 \pm 1.0$ \\
\hline
\end{tabular}


Fig. 3. The amout of acetone supplied and taken up during inhalation exposure at rest and during exercise. The mean values for eight subjects (series 1) and four subjects (series $2 a$ and $2 b$ ) are given.
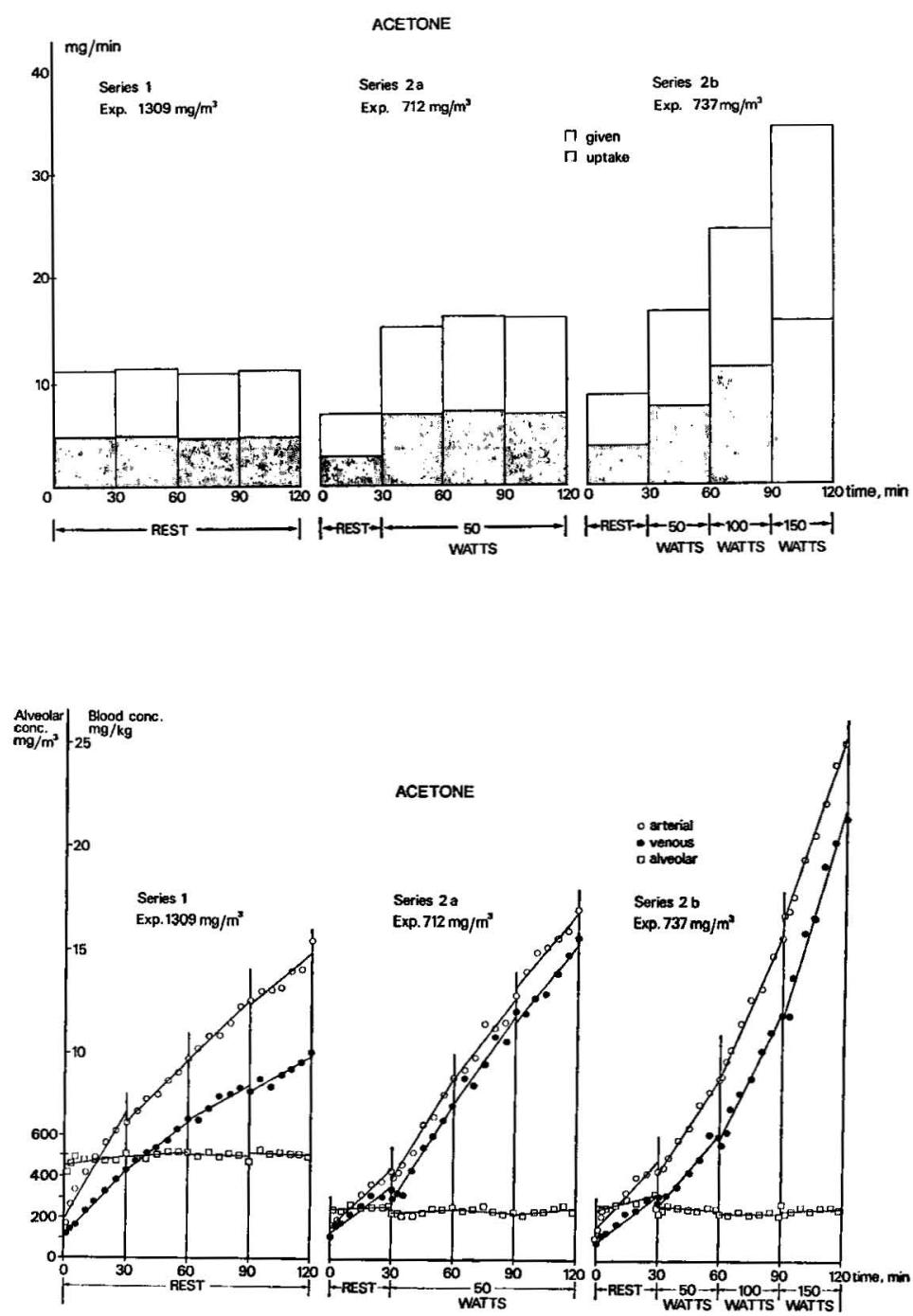

Fig 4. The acetone concentration in alveolar air, arterial blood, and venous blood during exposure to acetone at rest and during exercise. The mean values for eight subjects (series 1) and four subjects (series $2 a$ and $2 b$ ) are given. The regression lines were calculated for each $30-\mathrm{min}$ period. $(1 \mathrm{mg} / \mathrm{kg}$ $=0.017 \mathrm{mmol} / \mathrm{kg}$ )
Fig 5. The uptake of solvent in the lungs as the percentage of the amount supplied in relation to the quotient between the concentrations of alveolar and inspired air. The uptake was continuously measured for $30-\mathrm{min}$ periods, and the corresponding concentrations in alveolar air were based on values at the end of each 30-min period. Each symbol represents a mean value of four to eight subjects. The equation of the regression line was calculated on the basis of 58 such mean values. The number of exposed subjects was as follows: 14 for methylene chloride, 15 for trichloroethylene, 4 for both aliphatic and aromatic white spirit, 7 for styrene, 12 for xylene, 7 for toluene, and $8 \times 2$ for acetone (altogether about 80 subjects). Deviation from the line $(S D)= \pm 4.2 ; \quad r=$ - 0.95 .

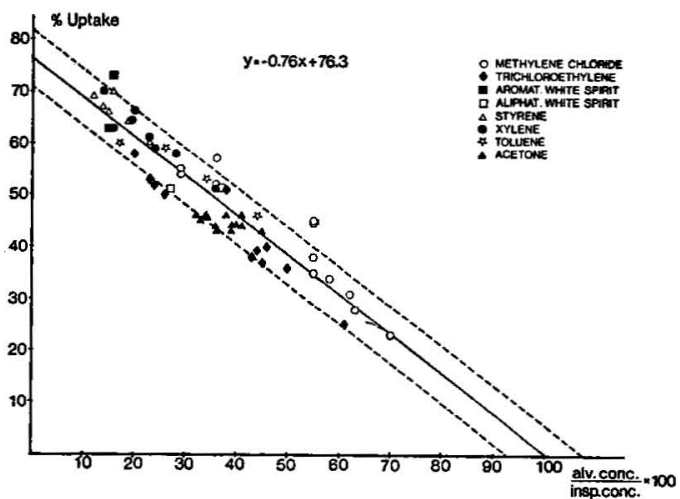


The endogenic acetone concentration in blood averaged $1.3 \pm 0.6 \mathrm{mg} / \mathrm{kg}(0.022 \pm$ $0.010 \mathrm{mmol} / \mathrm{kg}$ ). The acetone concentration in arterial and venous blood increased throughout the exposure in all series (fig 4). The venous blood concentration paralleled the arterial blood concentration but was on a somewhat lower level (fig 4). There was no sign of any equilibrium between the acetone concentrations in inspiratory air and in blood, and the acetone concentration increased in step with the increased amount taken up (fig 6). The arterial blood concentrations at the end of exposure averaged 15,17 and $25 \mathrm{mg} / \mathrm{kg}$ $(0.25,0.29$ and $0.44 \mathrm{mmol} / \mathrm{kg})$, in series $1,2 \mathrm{a}$ and $2 \mathrm{~b}$, respectively.

The ratio between the endogenic concentration in blood $(\mathrm{mg} / \mathrm{kg})$ and alveolar air $(\mathrm{mg} / \mathrm{l})$ averaged 765 . At the end of exposure the ratio between the acetone con-

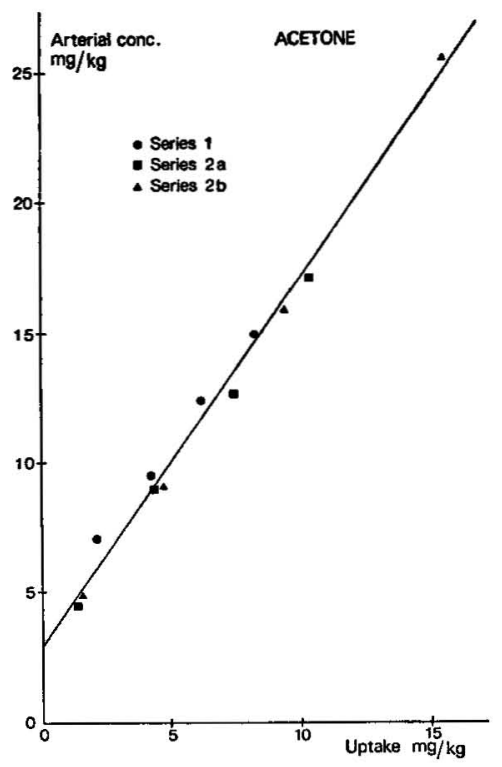

Fig 6. The acetone concentration in arterial blood in relation to uptake per kilogram of body weight during exposure to acetone at rest and during exercise. Series 1: exposure at rest $(30+30+$ $30+30 \mathrm{~min}$ ) to an average of $1,309 \mathrm{mg} / \mathrm{m}^{3}$; series $2 \mathrm{a}$ : exposure at rest $(30 \mathrm{~min})$ and $50 \mathrm{~W}$ on a bicycle ergometer $(30+30+30 \mathrm{~min})$ to an average of $712 \mathrm{mg} / \mathrm{m}^{3}$; series $2 \mathrm{~b}$ : exposure at rest (30 min) and 50,100 and $150 \mathrm{~W}$ on a bicycle ergometer $(30+30+30 \mathrm{~min})$ to an average of $737 \mathrm{mg} / \mathrm{m}^{3}$. Each value represents the mean value for eight subjects (series 1) and four subjects (series $2 a$ and $2 b$ ) at the end of each 30 min period. Regression line: $y=1.43 x+2.96$; $\mathrm{N}=12 ; \quad \mathrm{r}=0.99 ; \quad \mathrm{SD}= \pm 0.86$. $\quad(1 \mathrm{mg} / \mathrm{kg}=$ $0.017 \mathrm{mmol} / \mathrm{kg}$ ) centration in blood and in alveolar air was about 30 in series 1,70 in series $2 a$ and 100 in series $2 \mathrm{k}$. During the monitored elimination period the ratio was about 400,380 and 340 in series $1,2 \mathrm{a}$ and $2 \mathrm{~b}$, respectively. The mean value of the individual blood/air partition coefficients (mg -

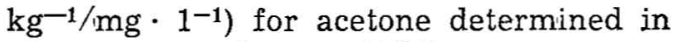
vitro was $275 \pm 14$ at $37^{\circ} \mathrm{C}$.

Fig 7 shows the concentrations in alveolar air, blood, and urine after the end of exposure. During the first $5 \mathrm{~min}$ after exposure, the concentration dropped rapidly in the alveolar air samples (fig 7). The concentration measured $5 \mathrm{~min}$ after exposure only amounted to about $8 \%$ of the concentration at the end of exposure in series 1 . The corresponding values in series $2 a$ and $2 b$ were 17 and $24 \%$, respectively. The concentration declined relatively slowly thereafter. Four hours later it had dropped to $3 \%$ in series 1 , to $10 \%$ in series $2 \mathrm{a}$, and to $15 \%$ in series 2b. The half-time for acetone in alveolar air, based on concentrations measured from $5 \mathrm{~min}$ to $9 \mathrm{~h}$ after exposure, averaged $4.3 \pm 1.1 \mathrm{~h}(\mathrm{~N}=15 \times 3 ; \mathrm{r}=-0.98 \pm 0.01$; $\mathrm{SD}=+0.082 \pm 0.006$ )

Table 5 presents the amount of acetone excreted via the lungs and kidneys. In series 1 , the subjects expired about $70 \mathrm{mg}$ of acetone during the first $4 \mathrm{~h}$ after exposure. The corresponding quantities for series $2 \mathrm{a}$ and $2 \mathrm{~b}$ were 80 and $150 \mathrm{mg}$. From the 4 th to the 20th hour after exposure, the subjects expired a further 50,80 and $200 \mathrm{mg}$ in series $1,2 \mathrm{a}$ and $2 \mathrm{~b}$, respectively.

The acetone concentration in blood dropped relatively slowly (fig 7). Two hours after concluded exposure, the arterial concentration was about $70 \%$ and the venous concentration about $80 \%$ of the concentration at the end of exposure. The half-time ( $0-2 \mathrm{~h}$ after exposure) for acetone in arterial blood averaged $3.9 \pm 0.7 \mathrm{~h}$ $(\mathrm{N}=10 \times 3 ; \mathrm{r}=-0.94 \pm 0.02 ; \mathrm{SD}=$ $\pm 0.045 \pm 0.015$ ). The half-time in venous blood $(0-4 \mathrm{~h}$ after exposure) averaged $6.1 \pm 0.7 \mathrm{~h}(\mathrm{~N}=14 \times 3 ; \mathrm{r}=-0.95 \pm$ $0.03 ; \mathrm{SD}= \pm 0.042 \pm 0.016$ ).

The individual urine/air partition coefficients $\left(\mathrm{mg} \cdot \mathrm{kg}^{-1} / \mathrm{mg} \cdot 1^{-1}\right)$ that were used for the headspace determination averaged $325 \pm 14$ and the mean endogenic acetone concentration in urine was $1.4 \pm 1.1 \mathrm{mg} / \mathrm{kg}$ $(0.024 \pm 0.019 \mathrm{mmol} / \mathrm{kg})$. The highest ace- 
tone concentration in urine appeared 3$3.5 \mathrm{~h}$ after exposure and was then at the same level as the highest concentration in venous blood (fig 7). This occurrence supports results of other studies indicating that the excretion of acetone by the kidneys appears to be the result of simple diffusion $(4,14)$. In series 1 , the subjects excreted an average of $8.5 \mathrm{mg}$ via the urine. In series $2 \mathrm{a}$ and $2 \mathrm{~b}, 8.5 \mathrm{mg}$ and $13.4 \mathrm{mg}$, respectively, were excreted via the urine (table 5). In the morning, about $20 \mathrm{~h}$ after exposure in all series, the acetone concentration in the alveolar air, and in the blood and urine, had dropped to the endogenic level. Excretion via the lungs and kidneys, corrected for endogenic acetone, was calculated to be about 16, 20 and $27 \%$ of the amount taken up in series $1,2 a$ and $2 b$, respectively (table 6). Excretion via the urine was only equivalent to about $1 \%$ of the total uptake.

The errors of the methods and analyses are presented in table 7 .

Fig 7. The concentration of acetone in alveolar air, blood and urine at the end of exposure and after concluded exposure up to the following morning. Series 1: exposure at rest $(30+30+$ $30+30 \mathrm{~min}$ ) to an average of $1,309 \mathrm{mg} / \mathrm{m}^{3}$; series 2a: exposure at rest $(30 \mathrm{~min})$ and $50 \mathrm{~W}$ on a bicycle ergometer $(30+30+30 \mathrm{~min})$ to an average of $712 \mathrm{mg} / \mathrm{m}^{3}$; series $2 \mathrm{~b}$ : exposure at rest $(30 \mathrm{~min})$ and 50,100 and $150 \mathrm{~W}$ on a bicycle ergometer $(30+30+30 \mathrm{~min})$ to an average of $737 \mathrm{mg} / \mathrm{m}^{3}$. The concentrations represent the mean values for eight subjects (series 1) and four subjects (series $2 \mathrm{a}$ and $2 \mathrm{~b}$ ). ( $1 \mathrm{mg} / \mathrm{kg}=$ $0.017 \mathrm{mmol} / \mathrm{kg}$ )

\section{Discussion}

A high affinity for blood (ie, a large blood/ air partition coefficient) is one important factor leading to a high initial relative uptake when solvent vapor is inhaled (3,

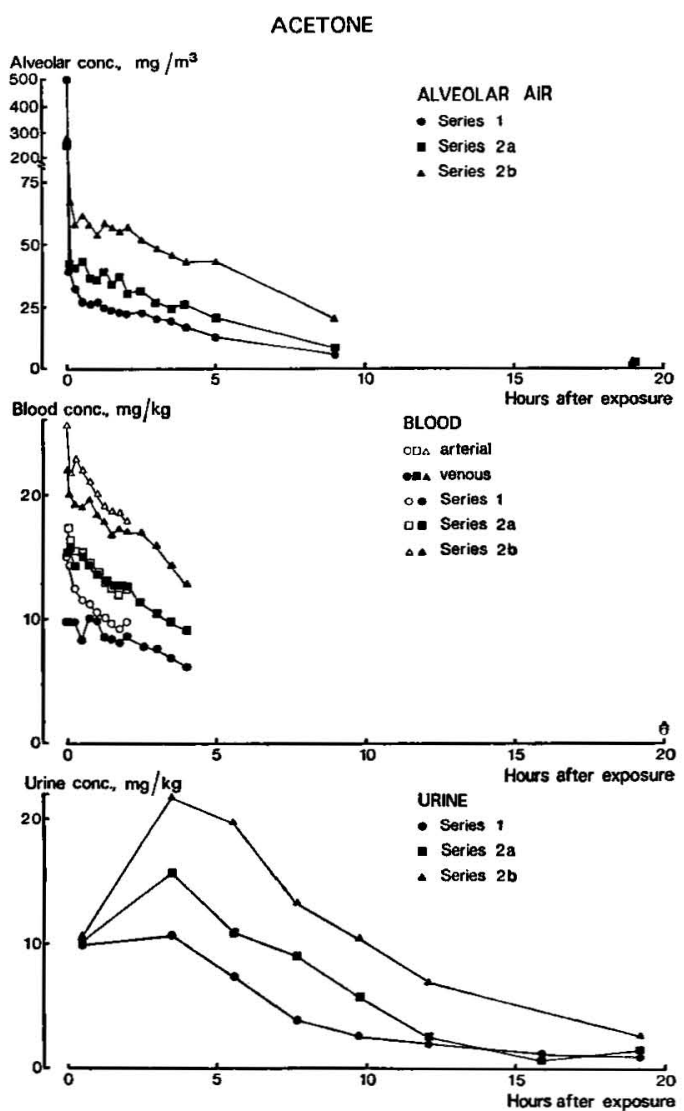

Table 5. Excretion of acetone $(\mathrm{mg})$ via the lungs and kidneys during different periods of time following inhalation exposure to acetone. Series 1: exposure at rest $(30+30+30+30 \mathrm{~min})$ to an average concentration of $1,303 \mathrm{mg} / \mathrm{m}^{3}$; series $2 \mathrm{a}$ : exposure at rest $(30 \mathrm{~min})$ and at $50 \mathrm{~W}$ on a bicycle ergometer $(30 \pm 30 \pm 30 \mathrm{~min})$ to an average concentration of $712 \mathrm{mg} / \mathrm{m}^{3}$; series $2 \mathrm{~b}$ : exposure at rest $(30 \mathrm{~min})$ and at 50,100 and $150 \mathrm{~W}$ on a bicycle ergometer $(30+30+30 \mathrm{~min})$ to an average concentration of $737 \mathrm{mg} / \mathrm{m}^{3}$. The mean values \pm the standard errors are given (series $1: N=8$; series $2 \mathrm{a}$ and $2 \mathrm{~b}: \mathrm{N}=4)$. ( $1 \mathrm{mg}=0.017 \mathrm{mmol})$

\begin{tabular}{|c|c|c|c|c|c|c|}
\hline \multirow{3}{*}{ Series } & \multicolumn{6}{|c|}{ Postexposure period } \\
\hline & \multicolumn{4}{|c|}{ Lungs } & \multirow{2}{*}{$\begin{array}{l}\text { Kidneys } \\
\text { Total } \\
0-1,200 \\
\text { min }\end{array}$} & \multirow{2}{*}{$\begin{array}{c}\text { Lungs }+ \text { kidneys } \\
\qquad \begin{array}{c}\text { Total } \\
0-1,200 \\
\text { min }\end{array}\end{array}$} \\
\hline & $\underset{\min }{0-16}$ & $\begin{array}{c}16-240 \\
\min \end{array}$ & $\frac{240-1,200}{\min }$ & $\begin{array}{c}\text { Total } \\
0-1,200 \\
\min \end{array}$ & & \\
\hline $\begin{array}{l}1 \\
2 a \\
2 b\end{array}$ & $\begin{array}{r}5.9 \pm 0.8 \\
6.2 \pm 0.4 \\
11.8 \pm 0.6\end{array}$ & $\begin{array}{r}63 \pm 9 \\
74 \pm 12 \\
138 \pm 33\end{array}$ & $\begin{array}{r}48 \pm 7 \\
77 \pm 21 \\
197 \pm 55\end{array}$ & $\begin{array}{l}117 \pm 17 \\
157 \pm 33 \\
347 \pm 88\end{array}$ & $\begin{array}{r}8.5 \pm 1.5 \\
8.5 \pm 1.5 \\
13.4 \pm 0.8\end{array}$ & $\begin{array}{l}125 \pm 18 \\
166 \pm 33 \\
360 \pm 89\end{array}$ \\
\hline
\end{tabular}


12). As the exposure time is prolonged, the magnitude of uptake is also influenced by the release of solvent from the blood by tissue uptake, biotransformation, and excretion. Acetone has a very large blood/ air partition coefficient [218 (5), 239 (9) and 245 (12) have been reported in other studies], which should result in a large initial relative uptake. Therefore, it seems remarkable that only about $45 \%$ of the acetone administered was taken up in the body when the initial relative uptake of the aromatic substances styrene and $x y-$ lene, the blood/air partition coefficients of which are about 10 times lower (12), was about $70 \%$ in similar studies $(2,7)$. As the relative uptake of acetone stayed at a constant low level during the whole exposure period, saturation of the blood could not be the limiting factor.

The fat/air partition coefficient (eg, oil/ air) is relatively large for most aromatic hydrocarbons, for example, benzene 492, toluene 1,471 and styrene 5,465 (12). This

Table 6. Total excretion of acetone via lungs and kidneys after the deduction of endogenic excretion. The mean values \pm the standard errors of the means are given. $(1 \mathrm{mg}=0.017 \mathrm{mmol})$

\begin{tabular}{crrrr}
\hline Series & Lungs $(\mathrm{mg})$ & Kidneys $(\mathrm{mg})$ & Total $(\mathrm{mg})$ & \% of uptake \\
\hline 1 & & & & \\
$2 \mathrm{a}$ & $88 \pm 15$ & $6.8 \pm 1.3$ & $95 \pm 16$ & $16 \pm 2$ \\
$2 \mathrm{~b}$ & $134 \pm 28$ & $7.2 \pm 1.0$ & $141 \pm 28$ & $20 \pm 4$ \\
\hline
\end{tabular}

Table 7. Tabulation of the errors of the methods and analyses and the intra- and intersubject variations.

\begin{tabular}{|c|c|c|c|c|}
\hline Variable & Calculation & $\begin{array}{l}\text { Number of } \\
\text { samples }\end{array}$ & $\begin{array}{l}\text { Error SD } \\
\text { the mea }\end{array}$ & $\begin{array}{l}\text { as } \% \text { of } \\
\text { in value }\end{array}$ \\
\hline $\begin{array}{l}\text { Acetone concentration } \\
\text { Expiratory air }\end{array}$ & $\begin{array}{l}\text { Difference between two gas samples } \\
\text { from the same foil bag before and after } \\
\text { exposure }\end{array}$ & $49 \times 2$ & $0.8 \mathrm{a}$ & \\
\hline $\begin{array}{l}\text { Alveolar air } \\
\text { Respiratory valve }\end{array}$ & $\begin{array}{l}\text { Difference between two consecutive } \\
\text { samples, one experimental occasion }\end{array}$ & $17 \times 2$ & $7.4 \mathrm{a}$ & \\
\hline Glass tube & $\begin{array}{l}\text { Difference between two consecutive } \\
\text { samples after exposure }\end{array}$ & $31 \times 2$ & $10.6 a$ & \\
\hline Relative uptake & $\begin{array}{l}\text { Difference between two consecutive } \\
\text { bags, one experimental occasion } \\
\text { Individual difference between series } 1 \\
\text { and } 2 \\
\text { Variation in the group (mean value for } \\
\text { series } 1 \text { and } 2 \text { ) }\end{array}$ & $\begin{array}{r}14 \times 2 \\
8 \times 2 \\
2 \times 8\end{array}$ & $\begin{array}{l}3.2^{a} \\
8.1^{a} \\
8.0^{b}\end{array}$ & \\
\hline \multirow[t]{2}{*}{$\begin{array}{l}\text { Partition coefficient } \\
\text { Blood/air } \\
\text { Urine/air }\end{array}$} & $\begin{array}{l}\text { Individual difference between series } 1 \\
\text { and } 2\end{array}$ & $8 \times 2$ & $\begin{array}{l}\text { blood } \\
3.7 \mathrm{a}\end{array}$ & $\begin{array}{l}\text { urine } \\
5.1 \mathrm{a}\end{array}$ \\
\hline & $\begin{array}{l}\text { Variation in the group (mean value for } \\
\text { series } 1 \text { and 2) }\end{array}$ & $2 \times 8$ & $4.2 \mathrm{~b}$ & $4.4^{b}$ \\
\hline \multirow[t]{2}{*}{$\begin{array}{l}\text { Endogen concentration } \\
\text { Blood, urine }\end{array}$} & $\begin{array}{l}\text { Individual difference between series } 1 \\
\text { and } 2\end{array}$ & $8 \times 2$ & $57 a$ & $89 a$ \\
\hline & $\begin{array}{l}\text { Variation in the group (mean value for } \\
\text { series } 1 \text { and } 2 \text { ) }\end{array}$ & $2 \times 8$ & $50 \mathrm{~b}$ & $76^{b}$ \\
\hline $\begin{array}{l}\text { Acetone concentration } \\
\text { Urine }\end{array}$ & $\begin{array}{l}\text { Difference between three samples from } \\
\text { the same urine portion }\end{array}$ & $29 \times 3$ & & $2.8 \mathrm{c}$ \\
\hline
\end{tabular}

$\begin{array}{ll}\text { a } & S D=\left\{\left[\sum D^{2}-(\Sigma D)^{2} / n\right] / 2(n-1)\right\}^{1 / 2} \\ \text { b } & S D=\left\{\left[\Sigma X^{2}-(\Sigma X)^{2} / n\right] /(n-1\}^{1 / 2}\right.\end{array}$

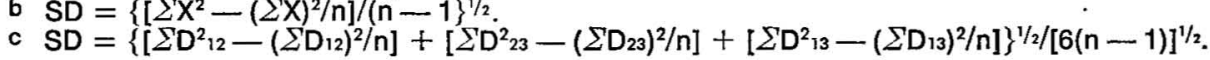


phenomenon should facilitate their passage through the two thin layers of epithelial and endothelial membranes which separate the alveoli from the capillaries. The fat affinity of acetone, which has been reported to be 86 (12), is much lower. This low affinity may affect the passage of acetone through the membrane and possibly be one of the explanations for the unexpected results.

However, the extremely high water affinity of acetone compared to the affinity of the aforementioned aromatic hydrocarbons is surely one factor contributing to the difference in relative uptake. When the relative uptake of substances with particularly large water/air coefficients (such as ethanol and acetone) is compared to the uptake of substances more soluble in fat, an inverse relationship is found between relative uptake and the blood/air partition coefficient (10). Relative uptake is calculated as the difference between the inspired and expired amount of solvent in relation to the inspired quantity. A high degree of solubility in water results in the dissolution of some solvent in saliva and mucous membranes on the way to the alveoli, which would then be reached by a concentration less than that in the inspiratory air. The mucous membranes of the mouth and throat are well vascularized, and there is probably a certain amount of uptake in these tissues. However, this uptake is not likely to represent a significant portion of total uptake since the epithelial layer is much thicker in these areas than in the alveoli and the blood/water partition coefficient is also less than one $(9,12)$.

Once in the alveoli, almost all of a substance highly soluble in blood should enter the bloodstream as long as saturation of the blood and/or membrane permeability does not hinder this entry. Thus, alveolar air should be relatively low in acetone concentration (11). The low acetone concentration, the high humidity, and the continuous air circulation are ideal conditions for the displacement of equilibrium so that acetone can be released from the mucous membranes and pass out of the body with expiratory air. This situation may cause somewhat higher analyzed values of acetone concentration in the expiratory samples and give a lower relative uptake than anticipated by the mechanisms affecting the relative uptake from the alveoli to the bloodstream.

The "acetone concentration in alveolar air remained constant at $30-40 \%$ of the concentration in inspiratory air throughout the entire exposure and was, thus, independent of total uptake. However, the alveolar air concentration (y $\mathrm{mg} / \mathrm{m}^{3}$ ) following exposure displayed a linear correlation with previous uptake $(\mathrm{x} \mathrm{mg} / \mathrm{kg}$ of body weight). One hour after the exposure the following relationship was obtained: $\mathrm{y}=3.7 \mathrm{x}+1.3 ; \mathrm{N}=15 ; \mathrm{r}=0.89 ; \mathrm{SD}=$ \pm 7.2 .

The acetone concentration in blood increased linearly as uptake increased (fig 6) and, thus, showed no tendency to equilibrate with the concentration in inspiratory air. The acetone concentration in arterial blood (y $\mathrm{mg} / \mathrm{kg}$ ) during exposure was linearly correlated with uptake $(\mathrm{x} \mathrm{mg} / \mathrm{kg}$ of body weight, $\mathrm{y}=1.4 \mathrm{x}+3.0 ; \mathrm{N}=12$; $\mathrm{r}=0.99 ; \mathrm{SD}= \pm 0.86$ ) (fig 6). The blood concentration after the end of exposure was also closely correlated to previous total uptake. When the arterial blood concentration (y mg/kg) $1 \mathrm{~h}$ after the exposure was plotted as a function of total uptake ( $\mathrm{x} \mathrm{mg} / \mathrm{kg}$ of body weight), the following linear relationship was obtained: $\mathrm{y}=0.77 \mathrm{x}+6.49 ; \mathrm{N}=15 ; \mathrm{r}=0.97 ; \mathrm{SD}$ $= \pm 1.1$. Therefore an arterialized capillary sample during or after exposure could be used as a biological sample in the estimation of the magnitude of uptake. The arteriovenous acetone difference was strikingly larger in series 1 than in series $2 a$ and $2 b$. One conceivable explanation may be that acetone is more readily distributed to certain tissues when a person is at rest than when he is carrying out physical work.

In previous studies of about 10 solvents in our laboratory, the excretion curves for arterial and venous blood already intersected about $5 \mathrm{~min}$ after exposure $(2,3)$, but in this study the concentration in venous blood stayed lower or equal to the arterial concentration during the $2 \mathrm{~h}$ of arterial blood monitoring. This is a rather remarkable result since the concentration should be higher in venous blood a short while after exposure because of excretion from organs to venous blood. The fact that the arterial concentration 
remained higher could be due to a continued administration of acetone released from the mucous membranes of the respiratory tract and saliva even after the conclusion of exposure.

\section{References}

1. Astrand I. Aerobic work capacity in men and women with special reference to age. Acta physiol scand 49 (1960): suppl 169.

2. Åstrand I, Engström J, Övrum P. Exposure to xylene and ethylbenzene: I. Uptake, distribution and elimination in man Scand j work environ health 4 (1978) 185194.

3. Astrand I. Uptake of solvents in the blood and tissues of man: A review. Scand $j$ work environ health 1 (1975) 199-218.

4. Briggs AP, Shaffer PA. The excretion of acetone from the lungs. $J$ biol chem 48 (1921) 413-428.

5. Brugnone F, Perbellini L, Grigolini L, Apostoli P. Solvent exposure in a shoe upper factory. Int arch occup environ health 42 (1978) $51-62$.

6. Dahlhamn T, Edfors ML, Rylander R. Retention of cigarette smoke components in human lungs. Arch environ health 17 (1968) $746-748$.

Received for publication: 9 October 1980
7. Engström J, Bjunström R, Åstrand I, Övrum P. Uptake, distribution and elimination of styrene in man: Concentration in subcutaneous adipose tissue. Scand $j$ work environ health 4 (1978) 315-323.

8. Israeli $\mathrm{R}$ vion, Zoref $\mathrm{Y}$, Tessler $\mathrm{Z}$, Braver J. Rea'ktionszeit als Mittel zur AcetonTLV-(MAK)-Wentbestimmung. Zentralbl Arbeitsmed 8 (1977) 197-199.

9. Lindqvist $T$. Fördelningskoefficlienterna blod/luft och vatuten/luft för några vanliga lösningsmedel. Arbetarskyddsverket, Sitockholm 1977. (Arbete och hälsa 1977: 8).

10. Nomiyama $K$. Nomiyama $H$. Respiratory retenition, uptake and excretion of organic solvents in man. Int Arch Arbeitsmed 32 (1974) $75-83$.

11. Patty FA. Industrial hygiene and toxicology. Vol 2, 3rd ed. Interscience, New York, NY 1963, pp 1726-1731.

12. Sato A, Nakajima T. Partition coefficientis of some aromatic hydrocarbons and ketones in water, blood and oil. $\mathrm{Br}$ ind med 36 (1979) 231-234.

13. Suzuki H. An experimental study on physiological functions of the autonomic nervous system of man exposed to acetone gas. Jpn ind health 15 (1973) 23-24.

14. Widmark EMP. Studlies in the acetone concentrattion in blood, urine and alveolar air: II. The passage of acetone and acetoacetic acid into the urine. Biochem $j 14$ (1920) $364-378$. 